Acta vet. scand. $1978,19,458-460$.

Brief Communication

\title{
HALOTHANE SENSITIVITY, THE H BLOOD GROUP SYSTEM AND PHOSPHOHEXOSE ISOMERASE (PHI) IN PIGS
}

\section{A LINKAGE STUDY OF PHYSIOLOGICAL IMPORTANCE *}

Previous investigations have clearly shown the existence of associations between halothane sensitivity, the $H$ blood group system and the PHI enzyme system in pigs (Rasmusen \& Christian 1976, Jorgensen et al. 1976). These associations which have considerable practical interest are most probably linkage phenomenons (Jørgensen 1977, Andresen \& Jensen 1977). The major recessive locus for halothane sensitivity (HAL) comprises the two alleles $N$ and $n, n$ being responsible for halothane sensitivity. The distances between this locus and the loci for $\mathrm{H}$ and PHI are still not known exactly. This communication aims at clarifying these problems.

Fourteen families (127 pigs), informative regarding the study of linkage, were selected from previously published investigations (Jørgensen et al., Jфrgensen, Jørgensen \& Wäfler 1978). In five families representing double backcross matings with respect to $H$ and $H A L$ (Table 1 ), two recombinants were observed. Lod score values (Morton 1955) for linkage between $\mathbf{H}$ and HAL are shown in Fig. 1. As each family consists of eight or more individuals no correction due to truncated selection has been made. Fig. 1 also shows lod score values from nine backcross-intercross matings. The overall lod score has maximum for $\theta=0.038$ with no evidence of heterogeneity among families $\left(\chi_{14 \mathrm{df}}^{2}=10.65, \mathrm{P}>0.70\right)$. Inclusion of two families (14 pigs) representing double backcross matings with known parental linkage phase gives a maximum lod score (17.72) for $\theta=0.029 \pm$ 0.025 , with an upper $95 \%$ confidence limit of 0.07 . This recombination fraction equals the distance between $\mathrm{H}$ and PHI $(\theta=$ 0.026, Andresen 1970), emphasizing the close linkage between $\mathrm{H}$ and HAL and the very close position of HAL and PHI.

Table 2 shows segregation of $\mathrm{HAL}$ and $\mathrm{PHI}$ in four families. Maximum lod score (12.64) was obtained for $\theta$ approaching $O$. Addition of the value published by others (Andresen \& Jensen 1978) gives a total of 23.67 , which makes the probability against linkage between HAL and PHI extremely small.

* The investigations were supported by the Danish Agricultural and Veterinary Research Council. 


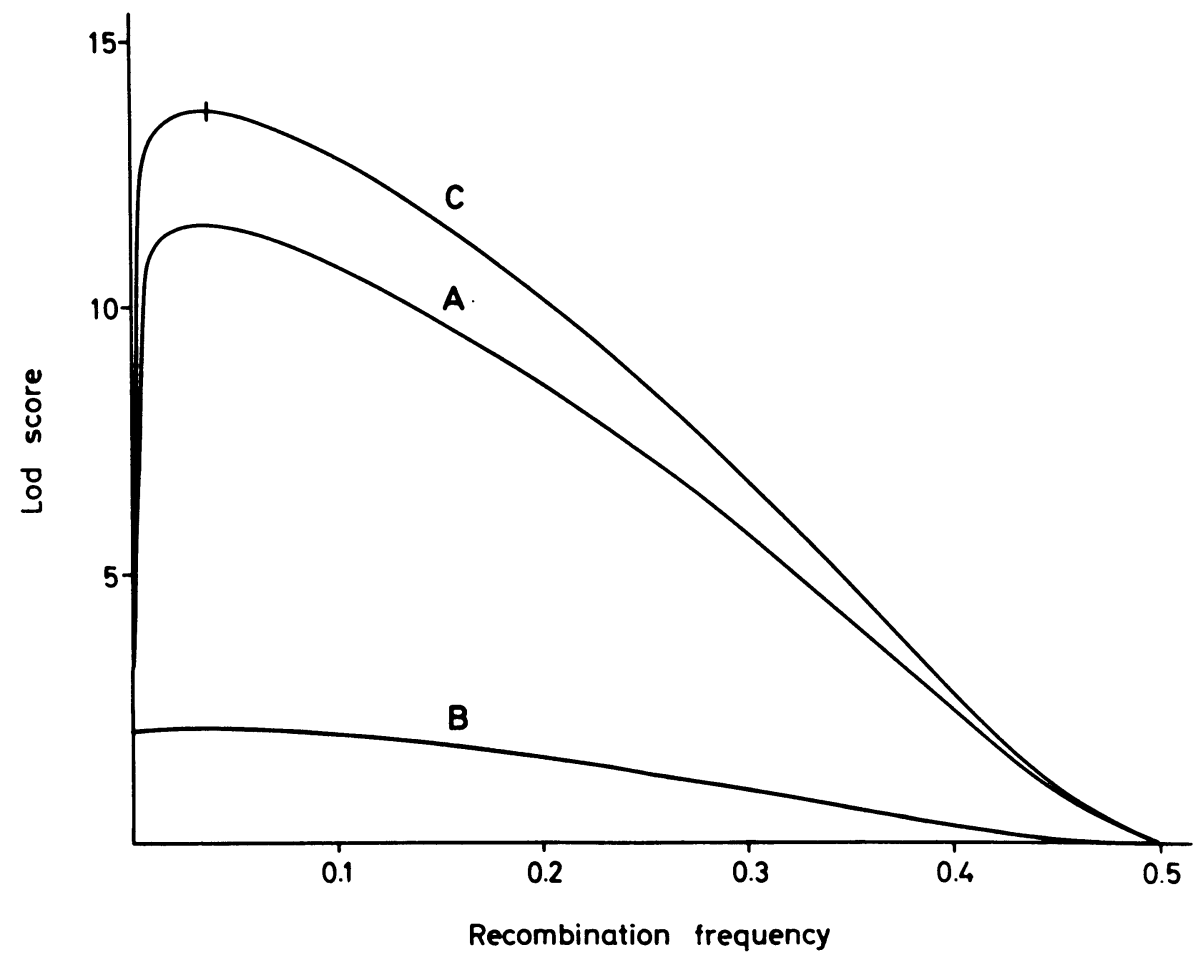

Fig u r e 1. Lod score values for linkage between halothane sensitivity and the $H$ blood group system. A: Double backcross matings. B: Intercross-backcross matings. C: Overall lod score.

Table 1. Segregation in double backcross matings with respect to locus for halothane sensitivity and the $H$ blood group locus.

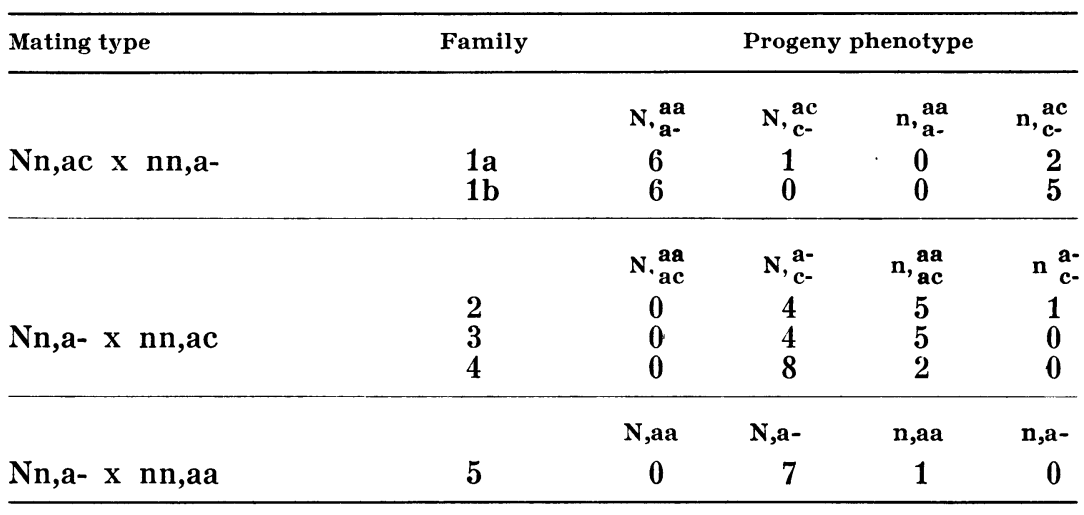

Four families gave information on linkage between HAL and PHI, HAL and $\mathrm{H}, \mathrm{H}$ and PHI. One recombinant between $\mathrm{H}$ and PHI was observed in family $1 \mathrm{a}$, and this animal was also a re- 
T a b l e 2. Segregation in double backcross matings with respect to locus for halothane sensitivity and the PHI locus.

\begin{tabular}{lcccccc}
\hline & & \multicolumn{4}{c}{ Progeny phenotype } \\
\cline { 3 - 6 } Mating type & Family & N,BB & N,AB & n,BB & n,AB \\
\hline & $1 \mathrm{a}$ & 0 & 7 & 2 & 0 \\
Nn,AB $x$ nn,BB & $1 \mathrm{~b}$ & 0 & 6 & 5 & 0 \\
& 3 & 0 & 4 & 5 & 0 \\
& 4 & 0 & 8 & 2 & 0 \\
& 5 & 0 & 7 & 1 & 0 \\
\hline
\end{tabular}

combinant between $\mathrm{H}$ and HAL, but not between HAL and PHI. This finding further underlines the very close or possibly even identical positions of HAL and PHI.

\section{ACKNOWLEDGEMENT}

The author cordially thanks Dr. Bent Larsen and Dr. P. Bräuner Nielsen for valuable discussions.

\section{Preben Fogd Jørgensen}

The Department of Physiology, Endocrinology and Bloodgrouping, Royal Veterinary and Agricultural University, Copenhagen, Denmark.

\section{REFERENCES}

Andresen, E.: Close linkage between the locus for phosphohexose isomerase (PHI) and the $\mathrm{H}$ blood group locus in pigs. Anim. Blood Grps Biochem. Genet. 1970, 1, 171-172.

Andresen, $E$. \& P. Jensen: Close linkage established between the HAL locus for halothane sensitivity and the PHI (phosphohexose isomerase) locus in pigs of the Danish Landrace breed. Nord. Vet.-Med. 1977, 29, 502-504.

Andresen, E. \& P. Jensen: The HAL-PHI linkage demonstrated by segregation among paternal sibs of Danish Landrace pigs. Nord. Vet.-Med. 1978, 30, 37-38.

Jørgensen, P. F.: Studier over sammenhængen mellem halothanf $\varnothing$ lsomhed samt blod- og enzymtypesystemer hos Dansk Landrace svin. (Studies on the association between halothane sensitivity, blood groups and enzyme systems in Danish Landrace pigs). Kgl. Vet.- og Landboh øjsk., Inst. Sterilitetsforskn. Årsberetn. 1977, 20, 101-108. København.

Jørgensen, P. F. \& P. Wäfler: Halothanfølsomhed og blodparametre hos Schweizisk Landrace grise. (Halothane sensitivity and blood parameters in Swiss Landrace pigs). Kgl. Vet.- og Landbohøjsk., Inst. Sterilitetsforskn. Årsberetn. 1978, 21, 39-48. København.

Jørgensen, P. F., J. Hyldgaard-Jensen, G. Eikelenboom \& J. Moustgaard: Phosphohexose isomerase ( $\mathrm{PHI}$ ) and porcine halothane sensitivity. Acta vet. scand. 1976, 17, 370-372.

Morton, N. E.: Sequential tests for the detection of linkage. Amer. J. hum. Genet. $1955,7,277-318$.

Rasmusen, B. A. \& L. L. Ćhristian: $\mathrm{H}$ blood types in pigs as predictors of stress susceptibility. Science 1976, 191, 947-948.

$$
\text { (Received May 16, 1978). }
$$

Reprints may be requested from: The Department of Physiology, Endocrinology and Bloodgrouping, Royal Veterinary and Agricultural University, Bülowsvej 13, DK-1870 Copenhagen V, Denmark. 